Journal of Management and Economic
Studies
2019, 1(2): 1-17 DOI: $10.26677 / \mathrm{TR} 1010.2019 .69$
Journal Homepage: $\mathrm{https://www.jomaes.org}$

\title{
Effective Housing Supply: Where and What to Supply?
}

\author{
Guowei Gu \\ Senior lecturer, London South Bank University, gug2@lsbu.ac.uk \\ Lynne Michael \\ Senior lecturer, London South Bank University, michael4@lsbu.ac.uk
}

\begin{abstract}
The aim of this paper is to examine the effective housing supply in terms of spatial location and the type of housing in Shanghai, China. Official property registration data is used to carry out interactive regression analysis. The study finds that low-rise housing projects in the suburbs show distinctive advantages over other categories of housing. The finding warrants the campaign launched in 2003, and strengthened in recent years by the municipal government, aimed at reducing the plot ratio of new property developments. This research contributes to a better understanding of issues surrounding housing supply in the local markets within China and provides the foundation for local governments to manage housing supply more effectively.
\end{abstract}

Keywords: Housing supply, Shanghai housing market, Supply quantity, Supply time, China

\section{Introduction}

Given the importance of housing, the attention of scholars has been drawn to housing studies for some time. Yet the focus of researchers has been on price and demand side (Gyourko and Saiz, 2006) and the supply of housing is understudied (Green, 2005; Wang et al, 2012).

DiPasqualh (1999) poses the question of 'why don't we know more about housing supply?' and formulates answers including the durable nature of housing, government interventions and the difficulty of modeling housing supply. DiPasqualh also highlights the fact that much of the literature employs aggregate data due to a paucity of information available from individual builders, investors or landlords which would help build understanding of the micro foundations of housing supply.

Shanghai is an economic powerhouse for China and its housing market has widespread impacts on the local economy. Since early 2000s, Shanghai has witnessed such a tremendous housing 
price hike that it threatens the stability and sustainability of the market. One of the primary causes of higher pricing is a shortage of supply. To remedy this problem, the maximum quantity of housing must be built, the development process facilitated and advances made to improve efficiencies in the supply chain.

This study concerns about the effectiveness of Shanghai housing supply in terms of spatial location and housing type. The second section comprises the literature review, section three the data, section four the analysis and the final section addresses conclusions to this study.

\section{Literature review}

A considerable amount of literature concerning housing supply focuses on the determinants of supply with particular attention paid to the factor of housing price. A number of scholars, including Vries and Boelhouwer (2005), investigate the relationships from the angle of market equilibrium. However, most researchers use regression methods and/or reduced form models to analyze how housing supply responds to housing price. This is in fact the price elasticity of housing supply.

An array of elasticities have been produced by researchers. Peng and Wheaton (1994) report a price elasticity of 1.1 in Hong Kong. Blackley (1999) states that long-run elasticities range from 1.6 to 3.7 for new housing supply in the US. After comparing two periods of time - boom year (1988) and slump year (1992), Pryce (1999) finds that the average price elasticities of housing supply are 0.58 (boom) and 1.03 (slump) in the UK. A fairly moderate elasticity of 0.08 is suggested by Mayer and Somerville (2000) in the US. Using flow models, Malpezzi and Maclennan (2001) find that the implied price elasticity in the pre-WW2 US is between 4 and 10 and between 6 and 13 in the post-WW2, while the implied price elasticity in the pre-WW2 UK is between 1 and 4 and between 0 and 1 in the post-WW2. White and Allmendinger (2003) also compare UK with USA and suggest a value for the long-run elasticity between 0 to 1 in the UK and 6 to 13 in the US. Price elasticities vary substantially from place to place with the lowest of 0.3 and the highest of 29.9 (Green, 2005). A further range of elasticities from -1.37 to 2.98 are presented by Goodman and Thibodeau (2008) after examining 133 U.S. MSAs. Ball (2010) demonstrates that price elasticities of supply are different at international, national, local and firm level. This claim is buttressed by Caldera Sánchez and Johansson (2011) who find that price elasticities vary substantially among 21 OECD countries with the lowest of 0.186 in the Netherlands and the highest of 2.014 in the USA. Although there is little research completed on the price elasticity of housing supply in China, Wang, et al (2012) conclude that national price elasticity of housing supply is between 2.8 and 5.6 and the elasticities vary from -7.70 to 37.05 for 35 cities (1.52 for Shanghai).

Another important factor is construction cost. Despite this major cost, little research has been undertaken and no consensus reached. 'Theory teaches that increases in the cost of construction should reduce the supply of new construction' (Somerville, 1999). A number of researches, however, offer alternative viewpoints.

Follain (1979) presents a positive relationship between construction labor wage and housing starts. This finding is supported by Topel and Rosen (1988). DiPasquale and Wheaton (1994) 
study the connection between the construction materials index and wage rates, and single family housing starts. The results are inconclusive.

By utilizing an entirely new set of micro-data of housing construction costs, Somerville (1999) argues that higher construction costs do reduce residential construction. This argument is upheld by Goodman and Thibodeau (2008). Somerville (ibid) further asserts that bias in the commercial cost indices used in existing housing supply studies is a likely cause for poor performance estimates of new single-family housing supply.

The factor of land use planning has been explored relatively extensively. However, a significant portion of existing literature dealing with housing focuses on the impact of planning regulations on housing price. Peng and Wheaton (1994) maintain 'restrictive land policies do not curtail housing production in the short run. Rather, higher prices actually temporarily encourage the production of housing units. In the long run, when the market returns to equilibrium, higher housing and land prices encourage the substitution of capital for land and hence raise the density of development'. This assertion could be partially explained by the substitution effect of capital for land in the long-run and by the housebuilder's practice of 'land banking' in the short-run (this practice is discussed in more detail by White, 1986; Tse, 1998; Lai and Wang, 1999). Moreover, 'planning gain' and development profit can cause disruption to housing output (Golland and Boelhouwer, 2002).

Nevertheless, 'a great number of studies have concluded that land regulations reduce the quantity of housing supply and therefore increase housing prices' (Hui and Soo, 2002). This conclusion is consistent with the findings of Mayo and Sheppard (2001), Vermeulen and Rouwenda (2007), Barker (2008) and Yan, Ge and Wu (2014). Mayer and Somerville (2000) specifically examine the relationship between land use regulation and new residential construction, concluding that 'land use regulations have significant effects in lowering the steady-state level of new construction' and that 'metropolitan areas with more extensive regulation can have up to 45 percent fewer starts'. Logically, 'housing production can be increased through relaxation of planning control' (Hui, 2004).

Pioneering study into how planning conditions under the lease tenure system impact upon housing provision was conducted by Hui and Soo (2002). This study indicates three lease conditions, i.e. the number of units, maximum gross floor area and number of storeys, show a strong positive correlation with housing supply. All analysis performed reveal statistically significant results.

The recognition of the impacts of these determinants enables a better understanding of the housing supply mechanism. The macro-management of housing supply would become more effective if the optimal location and type of housing were identifiable. Unfortunately, after reviewing the literature available, it is concluded that the macro-management of housing supply in China remains largely unexplored by previous researchers. Furthermore, due to lack of research the optimum location and housing type within China remains indeterminate.

\section{Method}

This research collected the data of 833 housing projects to analyze effective housing supply in Shanghai. The data set comprises both land and property information. 
The land market in mainland China adopted a LLTS (Land Lease Tenure System) in 2003 (Qu and Liu, 2012), which basically evolves from the HK LLTS (the HK system is elaborated by Peng and Wheaton, 1994 and Hui, 2004). Under the Chinese LLTS, all land is state-owned with no private land ownership permitted. Property developers [1] (the lessee) access the land through competitive means controlled by the government (the lessor) and pay to gain the right of using the land for a fixed time period. The maximum lease term for land exclusive to residential use is 70 years [2].

Once the right to use land is secured, the developer should possess two certificates: Land Planning Permit and Land Use Certificate. These two documents detail the approved constructions and set out development control. They are held by the developer and are not usually available to other parties. In Shanghai, the developer is also obliged to acquire a Certificate of Real Estate Ownership (CREO) and Pre-Sale Permit (PSP, only for pre-sale projects), prior to selling the property. CREO and PSP provide certain land information as well as property information.

This research examines 833 new housing projects from the official property platform, Properties Online [3], managed by Shanghai Bureau of Planning and Land Resources Administration. The time period studied is from 2004 to 2015 [4]. For each property, the information displayed contains CREO, PSP, dates of marketing, number of units to sell, the floor area to sell, marketing status (for sale or sold out), floor plan, sales contract, layout drawing and guarantee.

In the following empirical studies, we set housing supply quantity and housing supply time as two dependent variables and three binary variables and two interaction terms as independent variables (the details are specified later). The primary source of data is the platform aforementioned. Plot ratio was obtained from a number of large local estate agents.

\section{Findings}

Housing supply incorporates both quantity and time. In this empirical study, we use each of the two as one dependent variable and estimate the differential effects of location and type of housing on supply quantity and on supply time. Based on the results delivered from the interaction regression models, we then further test the optimal supply of different types of housing in different locations. Before we proceed, it is necessary to elaborate the two dependent variables.

Housing supply quantity is the total floor areas for sale recorded on the official platform for each project up to the end of 2015. Given that most of the housing projects are marketed by means of pre-sale (selling the property before completion, see Leung and Ma, 2013) and multitranche sale (selling the property multiple times), the amount of quantity this research exploits is the sum of floor areas of each tranche. The sum may not necessarily equal the grand total floor areas for each project because not all had finished the construction and the sales at the end of 2015 (which we may never know). We believe most had completed. The average rate of supply (defined as actual supply area divided by maximum allowable area comprising plot area multiplied by plot ratio) is $90.2 \%$.

Under a staged development and sales process, the housing supply time period refers to the 
duration from obtaining (leasing) the land to the first tranche of sale, plus the intervals of each sale afterwards until marketing is closed. In this research, we use two time periods. The first is the period from acquiring the land to the last tranche of sale up to the end of 2015 ("total period" for short and used for supply time in the following analysis if not stated otherwise). The second is the period from acquiring the land to the first tranche of sale ("first period" for short).

We begin with the estimation of the differences of mean supply quantity and supply time by utilizing the qualitative regressor of location. For simplicity, location is divided into central areas and suburbs. The former refers specifically to the areas within Inner-Ring road (see Figure 1), while the latter the large areas outside of the Inner-Ring road (similar definition favoured by Forsyth, 2012). We use binary variable $D_{c}$ to represent central location.

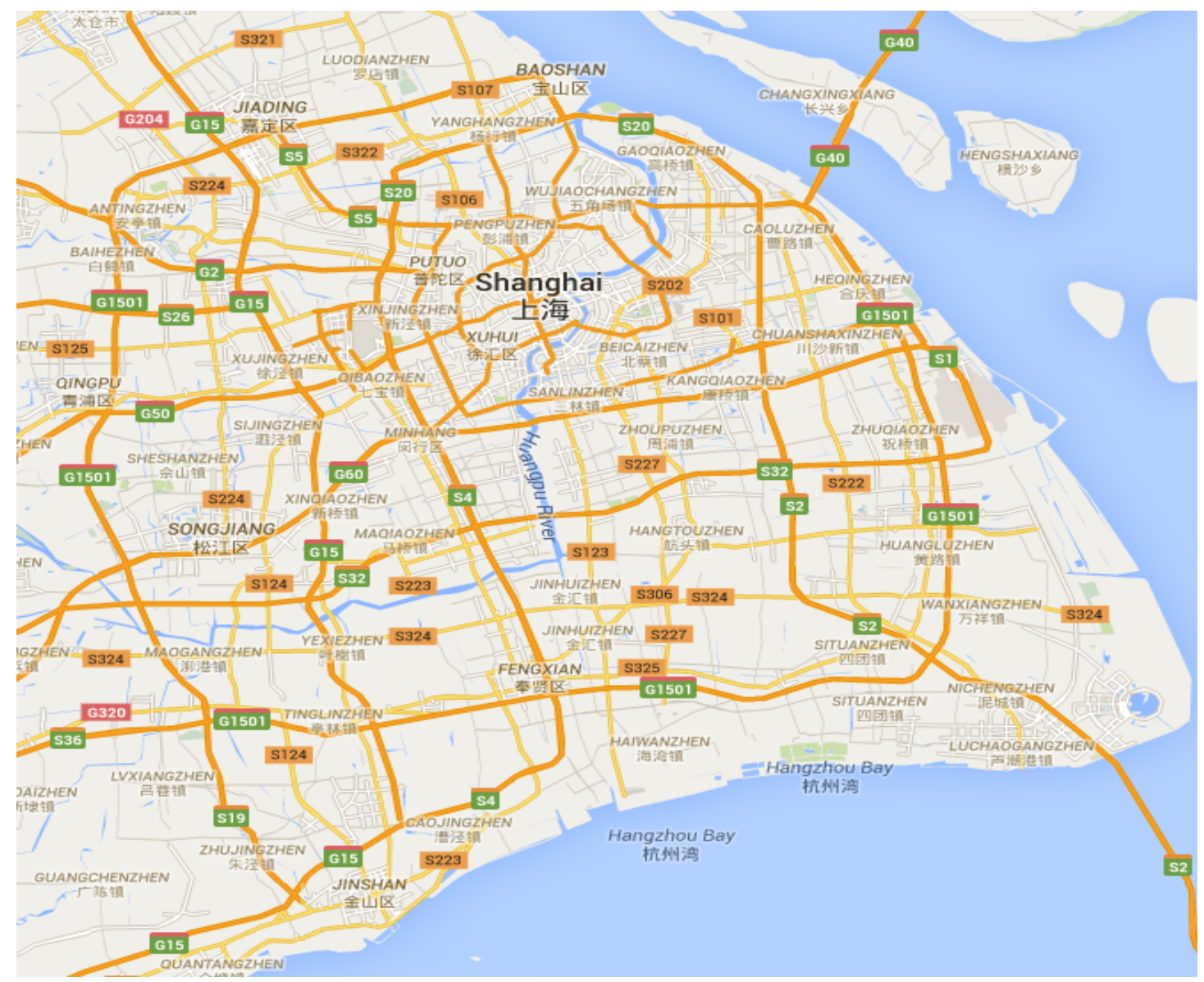

Figure 1 Shanghai Ring-Road Map

Notes: up to the end of year 2015 Shanghai metropolitan region can be spatially divided by four ring roads, i.e. the Inner Ring (IR), the Middle Ring (MR), the Outer Ring (OR) and the Suburban Ring (SR). The above Google Map of Shanghai illustrates the four rings. IR is the urban core in the centre while MR is the ring outside of IR. OR is designated as the road S20 and SR is G1501.

The housings supplied in downtown areas differ from that in the suburbs. In China many people still prefer to live in well-developed central areas which offer better job opportunities, 
education, health care, transportation, etc. The majority, however, eventuate residing in newlydeveloped suburban areas on account of affordability, more spacious dwelling and better environment. Thus the differences in demand and urbanization could be reflected in supply quantity. More conspicuous may be the difference of supply time for the two locations, given that centrally located projects are more complex and time consuming to develop. We use Equation $1 \mathrm{a}$ and Equation $1 \mathrm{~b}$ to estimate the mean supply differences resulted from different locations.

$$
\begin{aligned}
& Y_{1 i}^{\alpha}=\alpha_{10}+\alpha_{11} D_{c i}+\mu_{1 i}^{\alpha} ; \quad i=1,2, \ldots, 833 \\
& Y_{2 i}^{\alpha}=\alpha_{20}+\alpha_{21} D_{c i}+\mu_{2 i}^{\alpha} ; \quad i=1,2, \ldots, 833
\end{aligned}
$$

Where:

$Y_{1}^{\alpha}=$ housing supply quantity for location

$Y_{2}^{\alpha}=$ housing supply time for location

$D_{c}=1$ if project locates inside the Inner - Ring road, 0 otherwise

$\alpha_{10}=$ the mean supply quantity of being in suburb

$\alpha_{20}=$ the mean supply time of being in suburb

$\alpha_{11}=$ the differential quantity effect of being in centre

$\alpha_{21}=$ the differential time effect of being in centre

$\mu_{1}^{\alpha}=$ error term of supply quantity regression

$\mu_{2}^{\alpha}=$ error term of supply time regression

The regression results from Equation 1a and Equation $1 \mathrm{~b}$ are shown in Table 1. The coefficient of $D_{c}$ in supply quantity regression is negative, indicating that the quantity of supply in central districts is on average nearly fifteen thousand square meters lower than that in the suburbs. Moreover, it is significant at $1 \%$ (t-statistics -2.59). From Appendix 1 we can see that the mean site area in suburb $\left(68105 \mathrm{~m}^{2}\right)$ is larger than that in centre $\left(28488 \mathrm{~m}^{2}\right)$ and the mean plot ratio lower in suburb (1.42) is lower than that in centre (2.89). Multiplying site area by plot ratio, we get a larger allowed area in suburb $\left(96709 \mathrm{~m}^{2}\right.$ Vs. $\left.82330 \mathrm{~m}^{2}\right)$. Given that the allowed area is the maximum floor space a developer is able to build legally, the larger the allowed area is, the larger potential supply quantity becomes (proved by Hui and Soo, 2002). 
Table 1 Differential effects of project location on housing supply

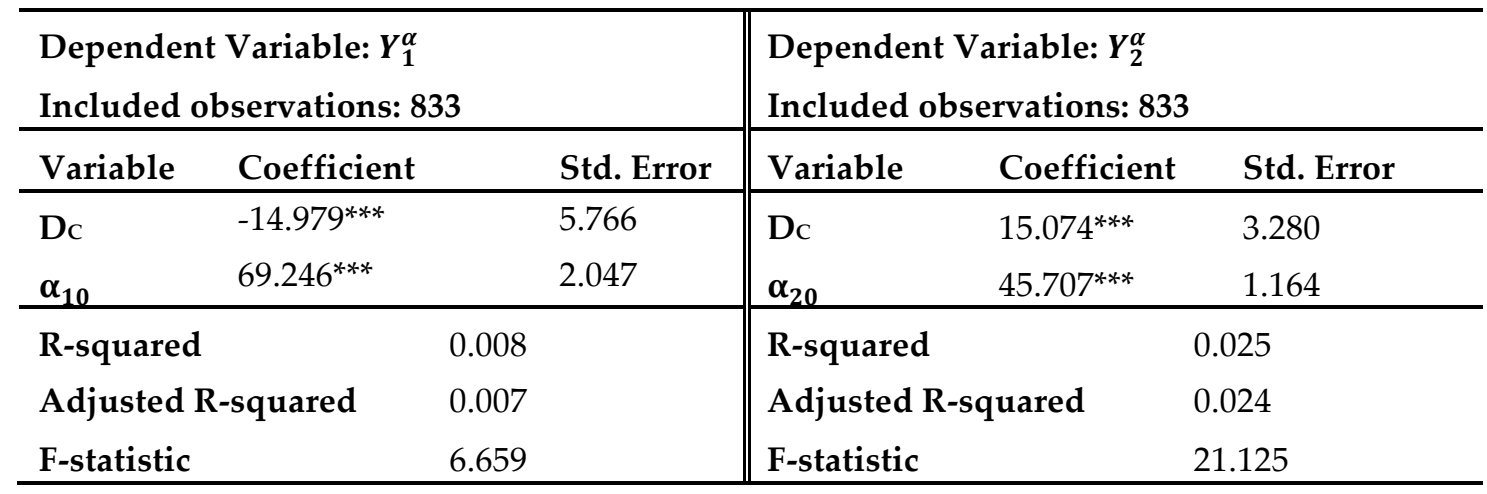

Note: “*” denotes statistical significance at $10 \%$ confidence, ${ }^{\text {“***” } \text { at } 5 \% \text { and }}$ “***” at $1 \%$.

Shanghai has been enjoying a booming economy for more than two decades. The continual prosperity acts like a magnet attracting millions of migrants from other parts of China and powers the large scale urbanization campaign. Given that the old central areas are severely short of development space, new construction must be carried out in the suburbs and countryside. Assisted by the favourable geographical condition in Shanghai, which sits almost entirely on an alluvial plain, projects in the fringe and newly converted farmland are capacious and relatively quick and easy to develop.

The differential supply time effect of location is statistically significant with a p-value less than $1 \%$. The mean supply time is more than 15 weeks longer in centres. This probably stems from urban resettlement.

Real estate development is a complicated enterprise in China. For residential projects, normally, the development process can generally be subdivided into segments subject to differing land development circumstances. Where the plot is "ripe land" (being shovel-ready for construction), development time is principally determined by the process of gaining government consents in terms of utility and facility usage, planning approval, construction permits etcetera, and to undertake project design and site development to the stage required for pre-sale (including any hoarding time if land is held until development conditions improve). When the plot is 'raw land' (agricultural land or brown field or urban resettled land), additional time may be required for land development or for resettlement. Agricultural land or brown field is relatively easy and quick to develop. However, urban land development involving resettlement in the central areas with a high density of old buildings is typically very arduous, a matter of the tug-of-war between developer and residents or business entities over the issue of cost/compensation (see Chen and Lai, 2013). The long and difficult resettlement process is the most likely reason why housing developments in central districts take a longer time.

The second qualitative regressor is type of housing. We divide 833 housing projects into three housing classes, i.e. high-rise apartment block $(\mathrm{H})$, low-rise apartment block (L) and singlefamily house $(\mathrm{V}$, in China it is usually called villa which includes detached, semidetached and terrace houses) according to plot ratio - "V" if plot ratio is lower than 0.8 ; " $\mathrm{L}$ " if plot ratio is between 0.8 and 1.5; " $\mathrm{H}$ " if plot ratio is higher than 1.5. The criteria are arbitrary but they are widely accepted in the industry. Housing is a heterogeneous product. The better understanding 
of the supply variances for different categories of housing will help to differentiate or prioritise housing supply in the market.

We introduce only one dummy variable of $\mathrm{D}_{\mathrm{c}}$ as the regressor of location in Equation 1a and Equation $1 b$ and two dummy variables of $D_{L}$ and $D_{H}$ as the regressors of housing type in Equation $2 \mathrm{a}$ and Equation $2 \mathrm{~b}$ to avoid "dummy variable trap". Suburban housing and singlefamily house are therefore assigned to be the benchmark categories in model 1 and model 2 respectively.

$$
\begin{gathered}
Y_{1 i}^{\beta}=\beta_{10}+\beta_{11} D_{L i}+\beta_{12} D_{H i}+\mu_{1 i}^{\beta} ; i=1,2, \ldots, 833 \\
Y_{2 i}^{\beta}=\beta_{20}+\beta_{21} D_{L i}+\beta_{22} D_{H i}+\mu_{2 i}^{\beta} ; i=1,2, \ldots, 833
\end{gathered}
$$

Where:

$D_{L}=1$ if the plot ratio of project is between 0.8 and $1.5,0$ otherwise

$D_{H}=1$ if the plot ratio of project is higher than $1.5,0$ otherwise

$\beta_{10}=$ the mean supply quantity of being single family house

$\beta_{20}=$ the mean supply time of being single family house

$\beta_{11}=$ the differential quantity effect of being lowrise apartment block

$\beta_{21}=$ the differential time effect of being lowrise apartment block

$\beta_{12}=$ the differential quantity effect of being highrise apartment block

$\beta_{22}=$ the differential time effect of being highrise apartment block

Table 2 exhibits the differential supply effects of three housing types. Of the six intercepts and coefficients, four are significant at $1 \%$ level and one coefficient $\left(\mathrm{D}_{\mathrm{L}}\right)$ for supply time is significant at $5 \%$ level and one $\left(\mathrm{D}_{\mathrm{H}}\right)$ for supply time is not significant. The R-squared and Adjusted Rsquared of two regressions are pretty low. As it is explained above, the two intercepts in Equation $2 \mathrm{a}$ and Equation $2 \mathrm{~b}$ represent the benchmark category of single-family house. In comparison with this base group, low-rise and high-rise apartment projects deliver more quantities in a shorter span of time.

\begin{tabular}{|c|c|c|c|c|c|}
\hline \multicolumn{3}{|c|}{$\begin{array}{l}\text { Dependent Variable: } Y_{1}^{\beta} \\
\text { Included observations: } 833\end{array}$} & \multicolumn{3}{|c|}{$\begin{array}{l}\text { Dependent Variable: } Y_{2}^{\beta} \\
\text { Included observations: } 833\end{array}$} \\
\hline Variable & Coefficient & Std. Error & Variable & Coefficient & Std. Error \\
\hline $\mathrm{D}_{\mathrm{L}}$ & $30.353^{* * *}$ & 5.640 & $\mathrm{D}_{\mathrm{L}}$ & $-8.381^{* *}$ & 3.280 \\
\hline $\mathrm{D}_{\mathrm{H}}$ & $24.685^{* * *}$ & 5.531 & $\mathrm{D}_{\mathrm{H}}$ & -5.035 & 3.217 \\
\hline$\beta_{10}$ & $44.349^{* * *}$ & 4.763 & $\beta_{20}$ & $53.160^{* * *}$ & 2.770 \\
\hline \multicolumn{2}{|c|}{ R-squared } & 0.034 & \multicolumn{2}{|c|}{ R-squared } & 0.008 \\
\hline \multicolumn{2}{|c|}{ Adjusted R-squared } & 0.032 & \multicolumn{2}{|c|}{ Adjusted R-squared } & 0.007 \\
\hline \multicolumn{2}{|l|}{ F-statistic } & 14.800 & F-statistic & & 3.357 \\
\hline
\end{tabular}

Table 2 Differential effect of housing type on housing supply

Note: "** denotes statistical significance at $10 \%$ confidence, "**" at $5 \%$ and "***" at $1 \%$. 
With regard to three types of housing, low-rise apartment is traditionally the dominant form of dwelling and is well received in Shanghai housing market. The popularity of it boils down to price and amenity. The high-rise is disadvantaged in terms of cost, design, fire safety and other issues. But in the last two decades, a large amount of high-rise residential towers have been erected to better accommodate a rapidly increased population. Single-family detached houses and terrace houses are generally regarded as luxury housing (especially the former).

In Shanghai, the policies regulating house (or villa) development have been greatly tightened by the planning authority since 2003 and in 2006 the landleasing for pure villa projects ceased to enable improved land use efficiency. Consequently, the construction of multi-family apartment blocks is encouraged as a result of the city's scarce land resource and huge inflow of migration. The regression results in Table 2 are supportive of the policies. However they also expose interesting differences between low-rise projects and high-rise ones - the former produces more quantities and consumes less time than the latter does. This is an important issue which is worth examining further.

Model 1 and 2 estimate the differential effect of housing location and type of housing on supply separately. If we want to know the differential effects on supply of housing location and type of housing jointly, for example to compare the supply of low-rise suburban apartment block with that of high-rise in central locations, we need to introduce interaction terms. These terms could subsequently help us to identify the best supply category. To this end, we recast model 1 and 2 by adding two interactive dummies between location and type of housing to allow the premiums of housing type dependent upon location.

$$
\begin{gathered}
\mathrm{Y}_{1 \mathrm{i}}^{\gamma}=\gamma_{10}+\gamma_{11} D_{c i}+\gamma_{12} D_{L i}+\gamma_{13} D_{H i}+\gamma_{14}\left(D_{c i} \times D_{L i}\right)+\gamma_{15}\left(D_{c i} \times D_{H i}\right)+\mu_{1 i}^{\gamma} ; \\
i=1,2, \ldots, 833 \quad \mathbf{3 a} \\
\mathrm{Y}_{2 \mathrm{i}}^{\gamma}=\gamma_{20}+\gamma_{21} D_{c i}+\gamma_{22} D_{L i}+\gamma_{23} D_{H i}+\gamma_{24}\left(D_{c i} \times D_{L i}\right)+\gamma_{25}\left(D_{c i} \times D_{H i}\right)+\mu_{2 i}^{\gamma} ; \\
i=1,2, \ldots, 833 \quad \mathbf{3 b}
\end{gathered}
$$

Where:

$$
\begin{aligned}
& \gamma_{10}=\text { mean supply quantity of villa in suburb } \\
& \gamma_{20}=\text { mean supply time of villa in suburb } \\
& \gamma_{11}=\text { differential quantity effect of being in centre } \\
& \gamma_{21}=\text { differential time effect of being in centre } \\
& \gamma_{12}=\text { differential quantity effect of being lowrise apartment block } \\
& \gamma_{22}=\text { differential time effect of being lowrise apartment block } \\
& \gamma_{13}=\text { differential quantity effect of being highrise apartment block } \\
& \gamma_{23}=\text { differential time effect of being highrise apartment block } \\
& \gamma_{14}=\text { differential quantity effect of being lowrise apartment block in centre } \\
& \gamma_{24}=\text { differential time effect of being lowrise apartment block in centre } \\
& \gamma_{15}=\text { differential quantity effect of being highrise apartment block in centre } \\
& \gamma_{25}=\text { differential time effect of being highrise apartment block in centre }
\end{aligned}
$$


The location factor and housing type factor are interacted in Equation $3 \mathrm{a}$ and Equation $3 \mathrm{~b}$ to produce more detailed information about the mean supply quantities and mean supply times for three different types of housing in centre and in suburb. The differential effects can be determined by contrasting appropriate coefficients. For example, the difference of mean supply time between low-rise building in centre and in suburb (Equation $3 \mathrm{~b}$ ) is

$$
E\left(Y_{2 i}^{\gamma} \mid D_{C i}=1, D_{L i}=1\right)-E\left(Y_{2 i}^{\gamma} \mid D_{C i}=0, D_{L i}=1\right)=\gamma_{21}+\gamma_{24}
$$

and the difference of mean supply time between high-rise building in centre and low-rise building in suburb is $\left(\gamma_{21}+\gamma_{23}+\gamma_{25}\right)-\gamma_{22}$. The complete regression results are demonstrated in Table 3 and 4.

Table 3 Differential effects of housing supply for different location and type of housing

\begin{tabular}{|c|c|c|c|c|c|}
\hline \multicolumn{3}{|c|}{$\begin{array}{l}\text { Dependent Variable: } Y_{1}^{\gamma} \\
\text { Included observations: } 833\end{array}$} & \multicolumn{3}{|c|}{$\begin{array}{l}\text { Dependent Variable: } Y_{2}^{\gamma} \\
\text { Included observations: } 833\end{array}$} \\
\hline Variable & Coefficient & Std. Error & Variable & Coefficient & Std. Error \\
\hline Dc & $75.867^{* *}$ & 38.47 & Dc & $121.190^{* * *}$ & 21.892 \\
\hline $\mathrm{D}_{\mathrm{L}}$ & $32.620^{* * *}$ & 5.63 & $\mathrm{DL}_{\mathrm{L}}$ & $-6.091^{*}$ & 3.204 \\
\hline $\mathrm{D}_{\mathrm{H}}$ & $30.574^{* * *}$ & 5.748 & $\mathrm{D}_{\mathrm{H}}$ & $-7.633^{* *}$ & 3.271 \\
\hline$D_{c} D_{L}$ & $-136.114^{* * *}$ & 44.439 & $\mathrm{Dc}_{\mathrm{c}} \mathrm{D}_{\mathrm{L}}$ & $-145.075^{* * *}$ & 25.289 \\
\hline $\mathrm{Dc}_{\mathrm{c}} \mathrm{D}_{\mathrm{H}}$ & $-94.229^{* *}$ & 38.992 & $\mathrm{Dc}_{\mathrm{c}} \mathrm{DH}_{\mathrm{H}}$ & $-103.950^{* * *}$ & 22.190 \\
\hline$\gamma_{10}$ & $43.190^{* * *}$ & 4.753 & $\gamma_{20}$ & $51.310^{* * *}$ & 2.705 \\
\hline \multirow{2}{*}{\multicolumn{2}{|c|}{$\begin{array}{l}\text { R-squared } \\
\text { Adjusted R-squared }\end{array}$}} & & R-squarec & \multicolumn{2}{|c|}{0.072} \\
\hline & & 0.051 & Adjusted & \multicolumn{2}{|c|}{0.066} \\
\hline \multicolumn{2}{|c|}{ F-statistic } & 9.942 & F-statistic & \multicolumn{2}{|c|}{12.807} \\
\hline
\end{tabular}

Note: "**" denotes statistical significance at $10 \%$ confidence, "**" at $5 \%$ and "***" at $1 \%$.

The differential effects of supply involving interaction terms are demonstrated in Table 3 and the average supply quantity and supply time for three types of housing in the centre or suburb are summarised in Table 4. Considering that there are only two projects of house in centre and six of low-rise in centre in our data collection, and that house (or villa) locates at the top end of housing market, we focus on these three housing categories in the following analysis for effective housing supply: low-rise in suburb, high-rise in suburb and high-rise in centre.

Table 4 Mean supply quantity and time for six housing categories

\begin{tabular}{|c|c|c|c|c|}
\hline Location & $\begin{array}{l}\text { Housing } \\
\text { Type }\end{array}$ & $\begin{array}{c}\text { Supply Quantity } \\
\left({ }^{\prime} 000 \mathrm{~m}^{2}\right)\end{array}$ & $\begin{array}{c}\text { Supply Time } \\
\text { (week) }\end{array}$ & $\begin{array}{c}\text { First Period } \\
\text { (week) }\end{array}$ \\
\hline \multirow{3}{*}{ Suburb } & House & 43.2 & 51.3 & 36.6 \\
\hline & Low-rise & 75.8 & 45.2 & 30.1 \\
\hline & High-rise & 73.8 & 43.7 & 30.2 \\
\hline \multirow{3}{*}{ Centre } & House & 119.1 & 172.5 & 127.5 \\
\hline & Low-rise & 15.6 & 21.3 & 18.8 \\
\hline & High-rise & 55.4 & 60.9 & 46.3 \\
\hline
\end{tabular}


Let's compare high-rise in the centre with low-rise and high-rise in the suburb. Undoubtedly, the high-rise in the centre is lagging behind both low-rise and high-rise of the suburb in both supply quantity and supply time (Table 4). The clustering of residential skyscrapers in downtown Shanghai verifies the principle of "substitution of capital for land" which is rightly reflected in our data (the mean plot ratio of projects in centre is 2.89 , while that in suburb is 1.42). However, the results in Table 3 and 4 point to the lower supply quantity of high-rise in centre compared with those of high-rise and low-rise in suburb per project, probably the consequence of the markedly smaller allowed area (details provided in Appendix 1):

The allowed areas of high-rise in centre $=22951 \times 3.04=69771 \mathrm{~m}^{2}$

The allowed areas of high-rise in suburb $=45586 \times 2.02=92084 \mathrm{~m}^{2}$

$$
=1.32 \times 69771 \mathrm{~m}^{2}
$$

The allowed areas of high-rise in suburb $=69844 \times 1.24=86607 \mathrm{~m}^{2}$

$$
=1.24 \times 69771 \mathrm{~m}^{2}
$$

The supply time of high-rise in the centre is longer than those of suburban high-rise and lowrise and it comes to the same conclusion when we use "first period". The explanations may lie with urban resettlement which has been discussed above. Additionally, the complexity in relation to construction procurement, building structure and site management for high-rise projects in centre may also contribute to a longer supply time.

Next, we compare suburban low-rise with suburban high-rise. The mean supply quantity of low-rise in suburb is $2.6 \%$ higher than that of high-rise in suburb. As we explained above, the allowed area is the maximum floor space the developer is allowed by planning authority to construct for sale purpose. It therefore determines the maximum supply quantity. However, the allowed area of low-rise in suburb is $86607 \mathrm{~m}^{2}$, slightly smaller than the allowable $92084 \mathrm{~m}^{2}$ of high-rise in the suburb. The main reason for higher supply quantity of low-rise in the suburb may be related with its higher utilization of the allowed area, which is $86.8 \%$, noticeably higher than $80.1 \%$ for high-rise in suburb (Table 5). In passing, the higher utilization also plays critical role when we compared supply quantity for two locations in model 1 and three categories of housing in model 3.

The allowed area is vital in determining the quantity of housing supply - the greater the allowable areas, the more the saleable areas and the higher the developers' earnings. Housing developers are thus incentivized to maximize the use of the allowed areas. However, the maximization will inevitably result in higher density and subsequent deterioration of living environment in terms of privacy, lighting, ventilation, health and safety. The problems could become much worse for high-rise residential blocks and could depress the price seriously. Hence the developer must strike a delicate balance between the utilization of the allowed area and the dwelling environment. 
Table 5 The comparison of supply for low-rise and high-rise outside of Inner Ring

\begin{tabular}{|c|c|c|c|c|c|}
\hline & MR(H) & OR(H) & SR(H) & \multicolumn{1}{c|}{ Total(H) or } \\
Mean(H)
\end{tabular}

Notes: (1). "L" denotes low-rise project while " $\mathrm{H}$ " high-rise one. (2) MR indicates the areas between Inner-Ring and Middle-Ring, while OR the areas between Middle-Ring and OuterRing and SR the areas between Outer-Ring and Suburban-Ring. OSR indicates the areas outside of Suburban Ring.

Table 5 details the mean supply quantity and supply time, the plot size, the plot ratio and the allowed area per project in four sub-suburb locales divided by three ring roads (see Figure 1). The distribution of the numbers of project appears to embody the sprawl of the city with significant amount of high-rise residential blocks are constructed outside of the Inner-Ring. But the amount of high-rise projects drops abruptly Outside Suburban-Ring (OSR) despite much larger space OSR covers (project number falls from 94 to 34). This may contribute to the lower mean supply quantity of high-rise in suburb as a whole (73.8 Vs 75.8). Given that the mean allowed areas of high-rise in four regions are uniformly larger than that of low-rise, it appears easy to conclude that the lower supply quantity of high-rise stems from its noticeably lower utilization of the allowed area.

The supply time of low-rise in the suburb is longer than that of high-rise in suburb. Generally speaking, high-rise building is more time-consuming to develop than low-rise one due to its complexity in terms of construction procurement and the impacts on surrounding areas. This may have less influence in relatively open/clear suburbs where a considerable proportion of high-rise buildings are in fact moderately high. These so called "mid-rise apartments" (or popularly called "mini high-rise) have recently been in vogue. It is usually 7-14 storeys high with a plot ratio between 1.5 and 2.0, possessing the merits of both low-rise and high-rise 
buildings.

The above comparison of supply time for the two categories is actually based on "total period" which spans from land leasing to the last sale. The inclusion of marketing time may complicate the discussion of supply time by embroiling many internal and external factors (from the selection of agent to the competition with competitors, from business management to government intervention). The use of "first period", which represents the time period from leasing the land to the start of sale, could simplify the issue. The mean first period of low-rise is 30.1 weeks while that of high-rise is 30.2 weeks.

In addition to the advantageous supply quantity and supply time over high-rise projects, lowrise projects are strongly supported by the municipal property development policy named "double increase and double decrease". Introduced in December 2003, the policy aims to create a more liveable city by increasing green land and public space and by reducing building volume and high-rise buildings. It even sets a cap plot ratio of 2.5 for residential buildings and 4.0 for commercial ones. Initially confined to the central areas, now the policy is applicable to the whole municipality.

\section{Conclusion}

Based on micro-data of 833 housing projects collected from an official source in Shanghai, this paper tends to shed light on effective housing supply in terms of spatial location and the type of housing in Shanghai. We regroup the 833 projects into six categories according to two locations - centre and suburb and three types of housing - house (villa), low-rise housing and high-rise housing.

The research proceeds in three steps. Firstly, we examine the difference of supply in different locations. By introducing one binary variable in the regression, we prove that the supply quantity is $14979 \mathrm{~m}^{2}$ higher in suburb than in centre per project and supply time is 15 weeks shorter in suburb per project. Secondly, we compare the supply for three types of housing using multiple regression models with two binary variables. The results show that low-rise is the most efficient type of housing both in supply quantity and supply time. Thirdly, with the aid of interaction regression model, we distinguish six categories of housing and calculate six quantities and times. We conclude that the optimal housing supply is low-rise housing projects in suburb.

In 2003, the municipal government of Shanghai launched a campaign called "double increase and double decrease" with the specific aim to reduce plot ratio for property projects. The policy initially covers the downtown areas. In recent years, it has been implemented throughout the municipality. Our research results strongly support the implementation of the policy as enabling a more effective, targeted planning regulation for housing development.

Although this research is confined to Shanghai, the results could be generalized to a group of distinctive mega cities in China known as 'first-tier cities' [5] that includes Beijing, Guangzhou and Shenzhen, as well as Shanghai. The other three cities are similar to Shanghai in terms of comparable scale, structure and market condition.

The Shanghai housing market has experienced noteworthy changes over the last few decades. 
In the last ten years, government has been leading the way in establishing an efficient and transparent housing information system. The framework of the system is taking shape, but it is still at an early stage. Armed with better quality data and more robust analytical tools, we can explore the dynamics of the process to better facilitate housing supply and to improve the Shanghai housing market.

\section{Notes}

1. In Chinese real estate industry, there is no section denoted specifically as housebuilder or homebuilder. However, the core business activity of most property developers is house building.

2. Housing can be divided into pure housing and commercial housing. The latter refers to the building of mixed uses (ground floor or/and low floors are for commercial uses and the above are for dwelling). Pure housing can secure a maximum land lease term of 70 years and commercial housing 50 years.

3. The website address is www.fangdi.com.cn. The registration of the projects on the website is mandatory for all developers who want to sell properties in Shanghai. 833 housing projects are selected from more than five thousand housings listed. They are new properties with land lease term of 70 years, enclosing a variety of housing types such as multi-family apartment (low-rise to high-rise), townhouse and single-family villa, but excluding affordable housing and resettlement housing.

4. The platform was launched in early 2004.

5. Generally speaking, there are two distinctively separate housing markets in China - the housing markets in first-tie-cities and the markets of other cities. The four cities have been experiencing rapid housing price hike for two decades due to severe housing supply shortage, even so in recent years, while the other cities are currently suffering from high stock and declining price.

\section{References}

Ball, M. et al. 2010. Housing supply price elasticities revisited: Evidence from international, national, local and company data. Journal of Housing Economics, 19, 255-268.

Barker, K. 2008. Planning policy, planning practice, and housing supply. Oxford Review of Economic Policy. 24-1, 34-49.

Blackley, D. 1999. The long-run elasticity of new housing supply in the US: empirical evidence for 1950-1994, Journal of Real Estate Economics and Finance. 18: 25-48.

Caldera Sánchez, A. and Johansson, A. 2011. The Price Responsiveness of Housing Supply in OECD Countries. OECD Economics Department Working Papers, No. 837, OECD Publishing. 
Chen, J and Lai, R. 2013. Pricing Relocation-Redevelopment Projects for City Expansion. Real Estate Economics. 41 (4), 925-957

DiPasqualh, D. 1999. Why don't we know more about housing supply? Journal of Real Estate Economics and Finance, 18:1.

DiPasquale, D and Wheaton, W.1994. Housing Market Dynamics and the Future of Housing Prices. Journal of Urban Economics, 35 (January), 1-27.

Follain, James R. 1979. The Price Elasticity of the Long-Run Supply of New Housing Construction. Land Economics, 55(2), 190-199.

Forsyth, A. 2012. Defining Suburbs. Journal of Planning Literature. 27(3), 270-281

Golland, A and Boelhouwer, P. 2002. Speculative housing supply, land and housing markets: a comparison. Journal of Property Research, 19(3) 231-251

Goodman, A. and Thibodeau, T. 2008. Where Are the Speculative Bubbles in U.S. Housing Markets? Journal of Housing Economics, 17-2: 117-37.

Green, K. et. al. 2005. Metropolitan-Specific Estimates of the Price Elasticity of Supply of Housing, and Their Sources. The American Economic Review, Vol. 95, No. 2.

Han, Q. 2004. China will restrict the construction of non-housing, luxury housing and big housing type. People Online. Available at: http://www.people.com.cn/GB/shizheng/1027/3082856.html. [Accessed 11 June 2014].

Hui, E. 2004. An empirical study of the effects of land supply and lease conditions on the housing market - A case of Hong Kong. Property Management, Vol. 22 No. 2, pp. 127-154.

Hui, E and Soo, J. 2002. Development Conditions and Supply of Housing: Evidence from Hong Kong. Journal of Urban planning and Development, 128:105-138.

Lai, N and Wang, K. 1999. Land-Supply Restrictions, Developer Strategies and Housing Policies: The Case in Hong Kong. International Real Estate Review. Vol. 2 No 1: pp. 143 - 159.

Leung, B and Ma, A. 2013. Exploration of the presale property market in China from an institutional perspective. International Journal of Strategic Property Management. 17(3), 248262

Li, Q and Chand, S. 2013. House prices and market fundamentals in urban China. Habitat International. Vol 40, pp 148-153.

Malpezzi, A and Maclennan, D. 2001. The Long-Run Price Elasticity of Supply of New Residential Construction in the United States and the United Kingdom. Journal of Housing Economics, 10, 278-306.

Mayer, C and Somerville, C. 2000. Land use regulation and new construction. Regional Science and Urban Economics, 30, 639-662.

Mayer, C and Somerville, C. 2000. Residential Construction: Using the Urban Growth Model to Estimate Housing Supply. Journal of Urban Economics, 48, 85-109. 
Mayo, S and Sheppard, S. 2001. Housing Supply and the Effects of Stochastic Development Control. Journal of Housing Economics,10,109-128.

Peng, R. and Wheaton, W. 1994. Effects of restrictive land supply on housing in Hong Kong: an econometric analysis. Journal of Housing Research, Vol. 5, pp. 263-91.

Pryce, G. 1999. Construction Elasticities and Land Availability: A Two-stage Least-squares Model of Housing Supply Using the Variable Elasticity Approach. Urban Studies, Vol. 36, No. 13, 2283- 2304.

Qu, W. and Liu, X. 2012. Assessing the Performance of Chinese Land Lease Auctions: Evidence from Beijing. Journal of real estate research. Vol.34, No.3 2012

Somerville, C. 1999. Residential Construction Costs and the Supply of New Housing: Endogeneity and Bias in Construction Cost Indexes. Journal of Real Estate Finance and Economics, 18:1, 43-62.

Topel, R. and S. Rosen. 1988. Housing investment in the United States. The Journal of Political Economy, 96:4, pp. 718-740.

Tse, R.Y.C. 1998. Housing price, land supply and revenue from land sales. Urban Studies,Vol. 35 No. 8, pp. 1377-92.

Vries, P and Boelhouwer, P. 2005. Local house price developments and housing supply. Property Management. Vol. 23 No. 2, 2005, pp. 80-96.

Wang, S. et al. 2012. The Estimation and Determinants of the Price Elasticity of Housing Supply - Evidence from China. Journal of Real Estate Research. Vol. 34, No. 3.

White, M and Allmendinger, P. 2003. Land-use Planning and the Housing Market: A Comparative Review of the UK and the USA. Urban Studies. Vol.40 Nos 5-6.

White, P. 1986. Land availability, land banking and the price of land for housing: a review of recent debates. Land Development Studies, 3, 101-111.

Yan, S., Ge, J. and Wu, Q. 2014. Government intervention in land market and its impacts on land supply and new housing supply: Evidence from major Chinese market. Habitat International. 44, 517-527 
Appendix 1 - Table of project summary

\begin{tabular}{|c|c|c|c|c|c|c|}
\hline $\begin{array}{l}\text { Project } \\
\text { character }\end{array}$ & $\begin{array}{l}\text { Project } \\
\text { quantity }\end{array}$ & $\begin{array}{l}\text { Mean } \\
\text { site } \\
\text { area } \\
\left(\mathrm{m}^{2}\right) \\
\end{array}$ & $\begin{array}{c}\text { Mean } \\
\text { plot } \\
\text { ratio }\end{array}$ & $\begin{array}{c}\text { Mean } \\
\text { supply } \\
\text { quantity } \\
\left(\mathrm{m}^{2}\right)\end{array}$ & $\begin{array}{c}\text { Mean } \\
\text { supply } \\
\text { time (week) }\end{array}$ & $\begin{array}{c}\text { Mean } \\
\text { first } \\
\text { period } \\
\text { (week) }\end{array}$ \\
\hline All & 833 & 63110 & 1.60 & 67371 & 47.6 & 33.2 \\
\hline $\begin{array}{l}\text { In centre } \\
\text { In }\end{array}$ & 105 & 28488 & 2.89 & 53655 & 60.8 & 46.3 \\
\hline suburb & 728 & 68105 & 1.42 & 69246 & 45.7 & 31.3 \\
\hline House & 131 & 115946 & 0.54 & 44349 & 53.2 & 38.0 \\
\hline Low-rise & 326 & 68826 & 1.24 & 74702 & 44.8 & 29.9 \\
\hline High-rise & 376 & 39746 & 2.28 & 69035 & 48.1 & 34.4 \\
\hline $\begin{array}{l}\text { House in } \\
\text { suburb }\end{array}$ & 129 & 112487 & 0.55 & 43190 & 51.3 & 36.6 \\
\hline $\begin{array}{l}\text { Low-rise } \\
\text { in suburb }\end{array}$ & 320 & 69844 & 1.24 & 75810 & 45.2 & 30.1 \\
\hline $\begin{array}{l}\text { High-rise } \\
\text { in suburb }\end{array}$ & 279 & 45586 & 2.02 & 73764 & 43.7 & 30.2 \\
\hline $\begin{array}{c}\text { House in } \\
\text { centre }\end{array}$ & 2 & 339027 & 0.26 & 119087 & 172.5 & 127.5 \\
\hline $\begin{array}{l}\text { Low-rise } \\
\text { in centre }\end{array}$ & 6 & 14493 & 1.23 & 15593 & 21.3 & 18.8 \\
\hline $\begin{array}{l}\text { High-rise } \\
\text { in centre }\end{array}$ & 97 & 22951 & 3.04 & 55431 & 60.9 & 46.3 \\
\hline
\end{tabular}

